
$O$ pportunities for riparian revegetation around the nation are numerous. Planting dormant nonnrooted cuttings, often called pole plantings, post plantings, or live stakes, is one technique often recommended for streambank stabilization and riparian buffer planting. Dormant nonrooted cuttings are easy to harvest and plant, and are inexpensive and effective. This method is limited to species that easily sprout from hardwood cuttings, such as willows (Salix spp. L. [Salicaceae]), cottonwoods (Populus spp. L. [Salicaceae]), and dogwoods (Cornus spp. L.

[Cornaceae]). Other species sprout from hardwood cuttings, but do not root as readily.

To plant nonrooted cuttings successfully in the arid and semi-arid West, it is extremely important that the base of the cutting extend about 20 to $30 \mathrm{~cm}$ (8 to 12 in) into the lowest water table of the year. The top of the cutting should extend out of the ground at least 25 to $30 \mathrm{~cm}$ (10 to 12 in) or high enough to be out of the shade cast by surrounding vegetation such as grasses or forbs. This allows the base of the cutting to act like a straw and pull water up the cutting, keeping the roots, stems, and leaves hydrated. In some riparian zones, especially severely altered systems, the lowest water table of the year can be several feet deep. Assuring roots can reach the lowest water table is often difficult when using bareroot or container plants. Nonrooted cuttings have been planted as deep $4 \mathrm{~m}$ (12 ft) using a long bar attached to a backhoe (Hoag and Ogle 1994). Generally, most riparian and stream protection projects require planting depths of 1 to $2 \mathrm{~m}$ ( 3 to $6 \mathrm{ft}$ ) and the biggest problem we faced was finding a way to dig a 1 - to 2 -m-deep (3 to $6 \mathrm{ft}$ ) hole quickly and efficiently. The Waterjet Stinger is the result of this equipment development effort.

\section{Waterjet Stinger}

The Waterjet Stinger was specially designed to use high-pressure water to hydrodrill a hole in the ground to plant unrooted hardwood cuttings. This is not new technology; in fact, it has been around for a long time. Andrews (1999) described using a water jet to drill
TABLE 1

List of parts and their costs for the Waterjet Stinger system.

Part letters correspond to Figures 1, 2, and 4

Parts

Location Number

Cost

(US\$; March 2001)

Pump and Suction (see Figure 1)

A $1 \frac{1}{4}$ inch plastic bypass hose

Bypass

$20 \mathrm{ft}$

$\$ 30.00$

B $1 \frac{1}{2}$ inch female cam lok to $1 \frac{1}{4}$ inch male hose shank Bypass

1

12.00

2 inch male pipe to male hose coupler (not shown)

Screen

1

5.80

C 2 inch plastic intake hose

Intake

$20 \mathrm{ft}$

40.00

D 2 inch male hose to female king

Intake

2

29.70 nipple hose cam lok coupler

E 2 inch hose clamps for plastic hose

Intake

2.70

F $\quad 2$ inch female pipe to male hose king nipple

Pump

5.30

G 2 inch female pipe to female hose-cam lok coupler

Pump

15.00

H Pump and motor (excludes freight)

495.00

I Roll cage for pump

65.00

Pressure Relief Valve (see Figure 2; top)

J $1 \frac{1}{2}$ inch pressure relief valve

Manifold 1

120.00

$\mathrm{K} 2$ inch galvanized metal tee

Manifold 1

7.00

L 2 inch to $1 \frac{1}{4}$ inch galvanized metal reducer

Manifold

3.00

M 2 inch to $1 \frac{1}{2}$ inch galvanized metal reducer

Manifold

1.64

N 2 inch male pipe to 2 inch male coupler nipple

O $1 \frac{1}{2}$ inch male pipe to female cam lok coupler

Manifold

8.00

Garden Hose Quick Coupler (see Figure 2; bottom)

P $1 \frac{1}{4}$ inch galvanized metal tee

Q 3-inch-long 1 1 $\frac{1}{4}$ inch galvanized metal nipple

Manifold

4.00

R $1 \frac{1}{4}$ inch to 1 inch galvanized metal reducer

Manifold

1.19

Manifold

5.00

S 1 inch to $3 / 4$ inch brass pipe to hose adapter

Manifold

6.58

T $3 / 4$ inch male hose to $3 / 4$ inch male hose adapter

Manifold

1.89

Nozzles and Connectors (see Figure 3 and 4)

U $3 / 4$ inch ball valve

Probe

10.00

V $3 / 4$ inch to $1 / 2$ inch elbow reducer

Probe

W $3 / 4$ inch to $1 / 2$ inch metal reducer

Probe

S 1 in to $3 / 4$ inch brass pipe to hose adapter

Probe

T $3 / 4$ Inch male hose to $3 / 4$ inch male hose adapter

Probe

$X \quad$ Female brass garden hose quick couplers

Hose

Y Heavy duty $5 / 8$ inch garden hose (100 psi rated)

120.00

Z Waterjets, manufactured by machinist

180.00

Total Costs

$\$ 1198.13$

Conversions: 1 in $=2.56 \mathrm{~cm} ; 1 \mathrm{ft}=0.3 \mathrm{~m}$ 


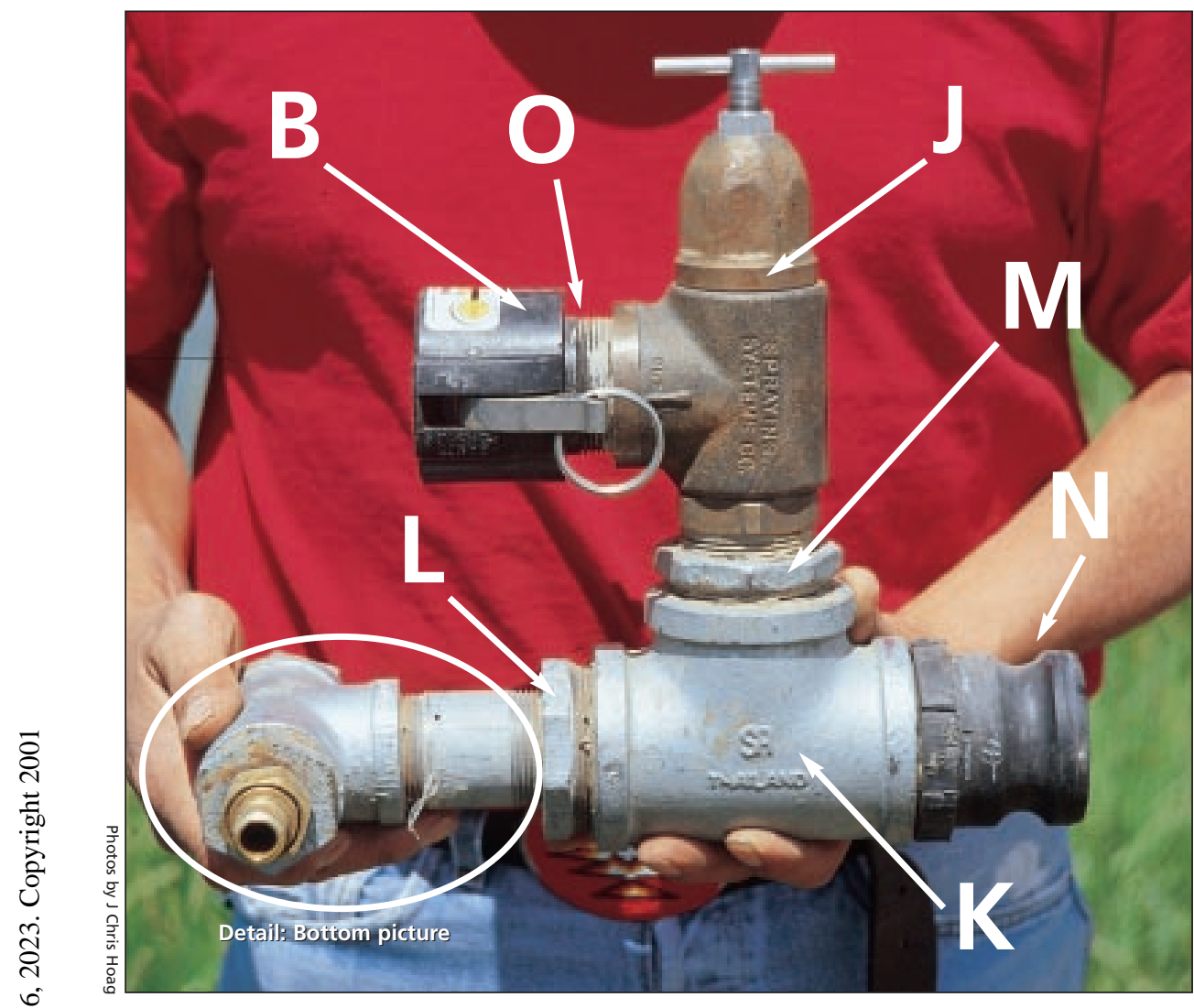

Figure 2 - Top: High pressure relief manifold.

Bottom: Garden hose quick coupler. Letters correspond to part descriptions in Table 1.

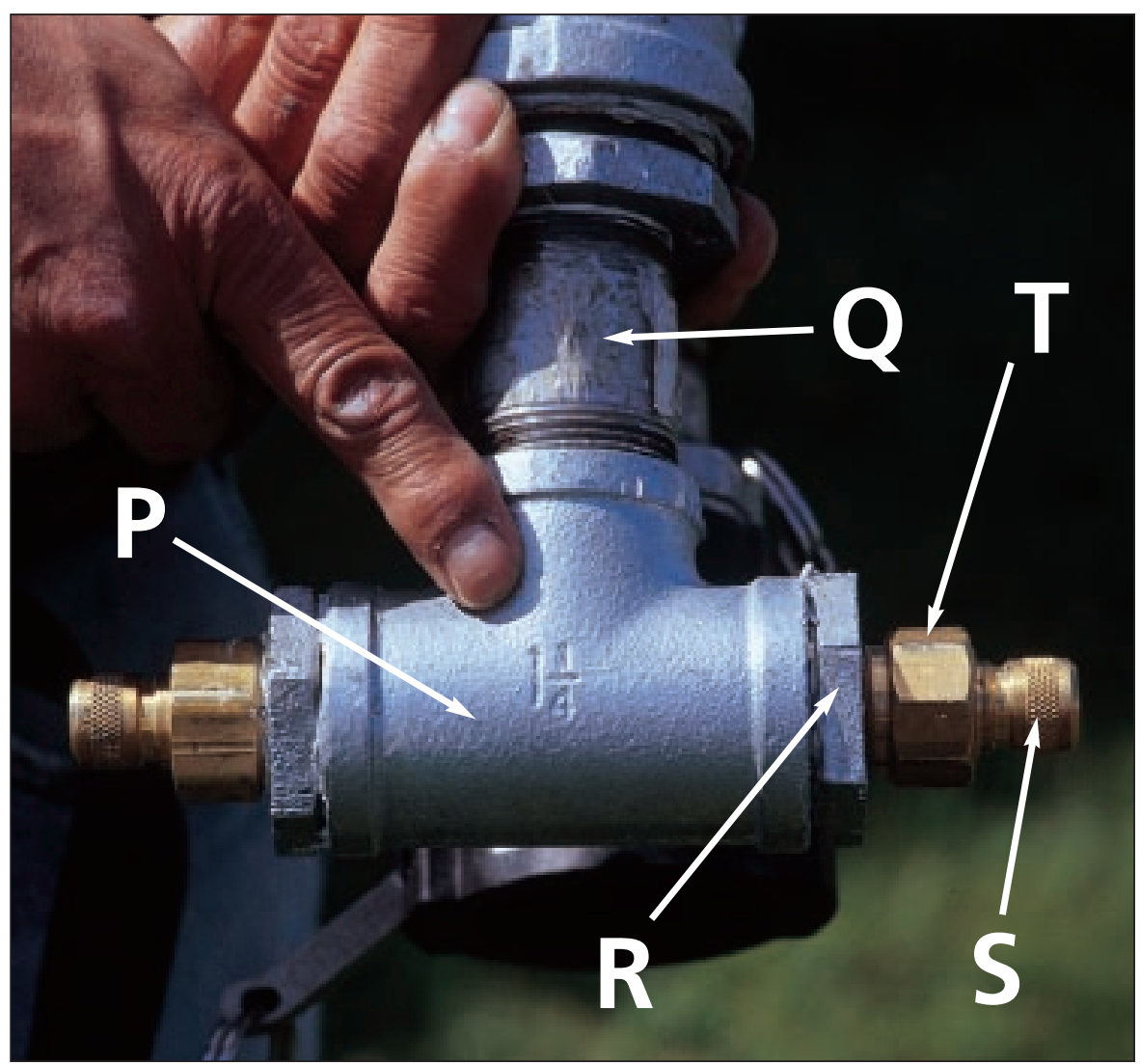

geotechnical test holes $10 \mathrm{y}$ ago, and Oldham (1991) reported using a water jet made with a steel pipe and pump to bore holes 1 to $2 \mathrm{~m}$ ( 3 to $6.5 \mathrm{ft}$ ) deep to plant willow cuttings.

Unfortunately, these earlier jets used steel pipes pounded or bent at the tip to increase pressure, but the pounding tended to weaken the steel and limit their useful life. Drake and Langel (1998) significantly improved the design by using a steel nozzle with 3 holes drilled in it. This nozzle was attached to a steel pipe. We modified that design and adapted it to fit our coarse soils and added several improvements to help the user become a more efficient planter.

The advantages of using our Waterjet Stinger to drill a hole for planting nonrooted cuttings are: 1) it is simple to operate and transport; 2) little training is necessary before operating; 3 ) hydrodrilling the planting hole is fast; 4) a large number of cuttings can be planted in a short period of time; 5) assures cutting is planted directly into a wet environment; 6) assures saturated soil conditions surround the cutting for a long period of time; and 7) liquefied soil will settle around the cutting eliminating air pockets in the rooting zone.

\section{WATERJET STINGER SPECIFICATIONS}

Our system consists of an ATV-mounted pressure pump that draws water from a nearby stream or water tank, a pressure relief valve, and 2 sets of hoses and nozzles (Waterjet Stingers) so 2 planting teams can drill holes simultaneously.

\section{High-pressure Pump}

Initially, we thought a 1600-psi pressure washer was ready made for this application. The pressure washers have more than enough water pressure, but they tend to blow all the soil out of the hole for the first few centimeters making the job pretty messy. However, the main problem is that pressure washers do not put out enough water volume, typically only about 7.5 to $11 \mathrm{l} / \mathrm{min}$ (2 to 3 $\mathrm{gal} / \mathrm{min}$ ). After the hole is drilled, very little water remains in the hole to hydrate the cuttings. Therefore, we do not recommend using a pressure washer. 

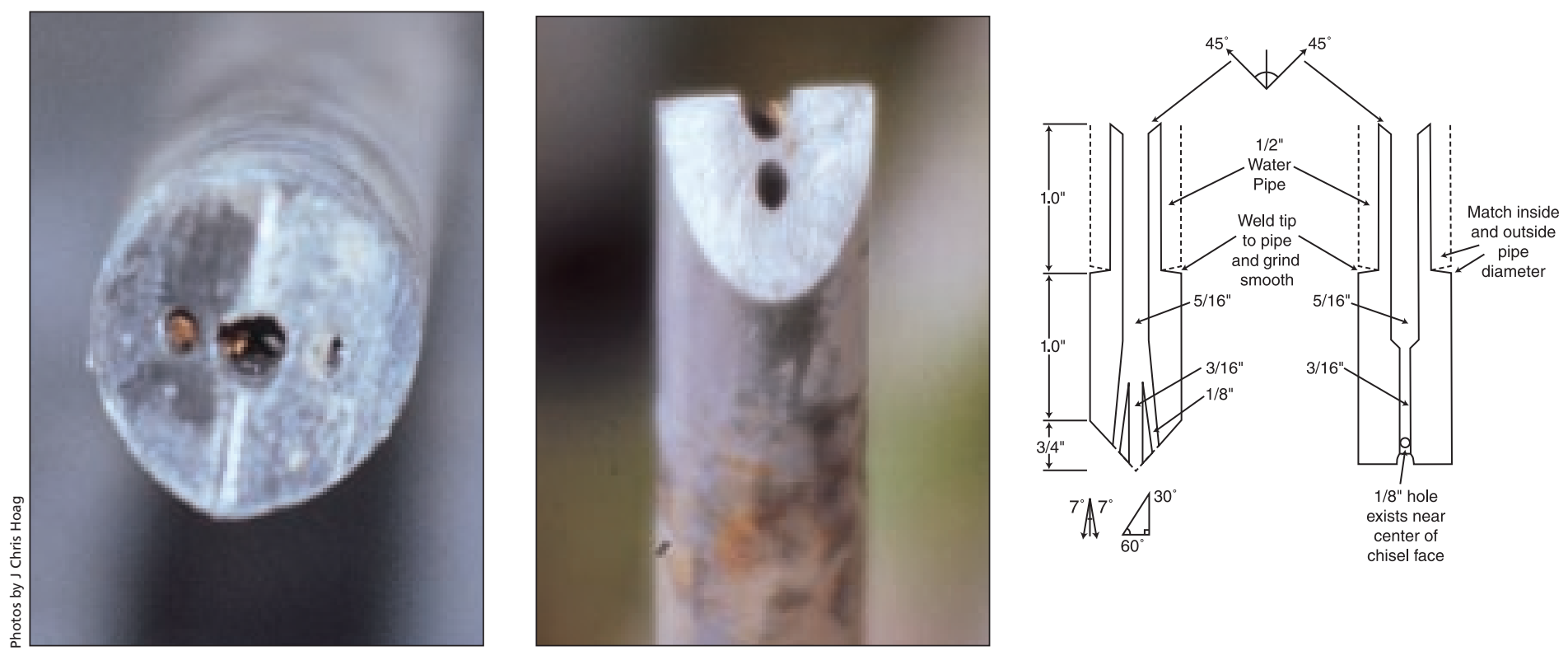

Figure 3 - Schematic of the waterjet nozzle from Drake and Langel (1998).

After additional research, we determined that the basic specifications for the pump were: 1) gasoline powered; 2) small enough to fit on the back of an ATV; 3) output of at least 80 psi or higher; 4) $450 \mathrm{l} / \mathrm{min}(120 \mathrm{gal} / \mathrm{min})$ output; and 5) vertical lift of at least $5.5 \mathrm{~m}$ $(18 \mathrm{ft})$. Many different pumps on the market will meet these specifications. We found an IPT pump (Figure 1) with the following specifications: 1) 27,000 1/h (7200 gal/h), 61-m (200-ft) head, 88 psi max; 2) self priming pump with $5 \mathrm{~cm}$ (2 in) NPT suction and discharge ports; 3) aluminum closed impeller; 4) cast aluminum housing; 5) cast iron volute; 6) built-in check valve; 7) water and trash pump strainer $(5 \mathrm{~cm}$ [2 in]; 8) low weight $(-29 \mathrm{~kg}[-64 \mathrm{lb}])$.

\section{Pressure Relief Valve}

For safety, a pressure relief valve should be installed so when both waterjets are shut off, the water from the pump will bypass back into the stream or other water source, decreasing pressure on the hoses and pump and eliminating the need to turn the pump on and off. A manifold (Figure 2) was designed to fit on the pump; it allows water to flow from the stream to either Waterjet Stinger or the bypass hose. When a specific internal pressure is reached inside the manifold, the water will divert to the bypass hose and back into the stream automatically.
The garden hose quick coupler manifold allows 2 waterjets to run simultaneously (Figure 2). It is attached to the main manifold just past the pressure relief valve. Quick couple attachments (available at most lawn and garden stores) are used for simple connections, reduce the possibility of stripping the threads on the hose ends, and to allow the hoses to be hooked up in either direction. Water is delivered through 30 -m-long (100-ft) heavy-duty $1.6 \mathrm{~cm}$ (5/8 in) garden hoses with a pressure rating of 100 psi.

\section{Nozzle}

The nozzle, made of stainless steel (Figure 3), can be made by a local machinist. The nozzle is welded to a 1.3-cm-diameter (0.5-in) steel pipe 1.5 to $1.8 \mathrm{~m}$ long $(5$ to $6 \mathrm{ft}$ ). A T-handle, made from $3.8 \mathrm{~cm}$ (1.5 in) tubular steel was added to the top. We also added a ball valve to turn the water on and off (Figure 4).

After testing the nozzles in the field, we welded a set of 3 vanes to the bottom of the probes (Figure 5). The vanes are $10 \mathrm{~cm}$ ( 4 in) long, tapering up and down the handle, and about $1.6 \mathrm{~cm}(0.6$ in) tall. The vanes increase the diameter of the hole so wider diameter cuttings can be inserted, especially in compacted soil layers like clay and some silt soil. Vanes also allow the user to nudge gravel slightly out the way in the hole, particu- larly since it is almost impossible to get any leverage on gravel with the smooth pipe. In cobbly soils the vanes provide little benefit.

\section{PLANTING PROCESS}

At the planting site, hoses are laid out parallel to the stream channel. The 2 waterjets can be operated with 2 separate crews. One crewmember runs each waterjet and the other crewmembers transport the cuttings and push them into the holes after they are hydrodrilled. As the holes are hydrodrilled and planted, the ATV with the pump can be relocated and the process starts again. If the streambank is too high and the lift too great to get water from the stream to the pump, the pump can be dismounted from the ATV and placed on a flat shelf that is cut right into the streambank. This way the pump is placed closer to the water and the lift is reduced.

Once the pump is set up and pushing water to the waterjets, hydrodrilling holes can begin. Vegetated planting sites are scalped down to mineral soil to remove competing above ground biomass. The waterjet is placed in the center of the scalp and the ball valve is turned on. At this point, most beginning users get nervous about being splashed with water. We have found that water rarely splashes, rather it tends to bubble as it liquefies the soil. Turn on slowly to full volume. Splashing 


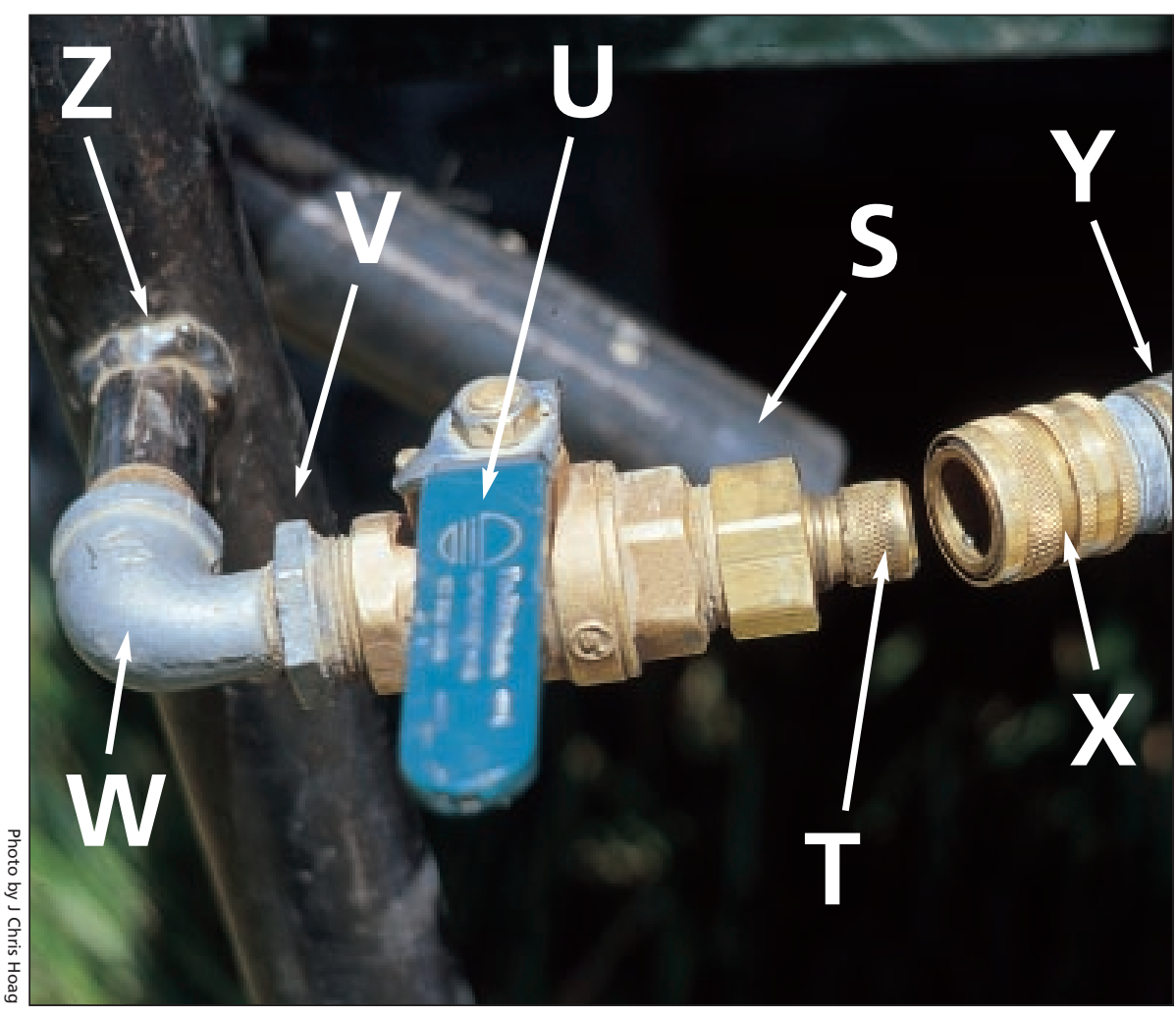

Figure 4 - Detail of connection at top of Waterjet Stinger showing ball valve. Letters correspond to part descriptions in Table 1.

might occur if the hydrodrilling is attempted on soils that are crusted or have a hard layer. However, as soon as the waterjet goes through the surface layer of soil, the splashing is eliminated (except in gravelly soils).

Once water starts jetting out of the nozzle, the waterjet will slowly start sinking into the ground. If a hard layer is encountered, the waterjet will stop. If the user leaves the waterjet in place and lets the water work on the layer, eventually it drills through it. We have demonstrated this on several sites including one with a $15-\mathrm{cm}$ thick (6-in) hard calcic layer and another with a $60-\mathrm{cm}$ thick (24-in) layer of decomposed granite. If medium sized rocks (with lots of fines around them) are encountered, the user must wiggle the jet back and forth until the water can find a way around it. This does make a larger hole below the surface, but the liquefied soil will normally settle back into place after the cutting has been installed.

As the waterjet liquefies the soil, it will continue down until it hits something it cannot cut through, the T-handle hits the ground, or the user stops. We have held the waterjet at a stationary point to have the water cut further into the soil. We have been able to duplicate Drake and Langel's (1998) depth of $2 \mathrm{~m}$ $(6.6 \mathrm{ft})$. The depth the waterjet will penetrate depends mainly on the soil texture and the length of the probe.

The waterjet probe has a diameter of $1.3 \mathrm{~cm}(0.5 \mathrm{in})$, but the user should be planting cuttings with diameters of at least $2 \mathrm{~cm}(0.75$ in) or greater (Hoag 1993; Bentrup and Hoag 1998). In order to get larger diameter cuttings in the hole, the soil needs to be liquefied all the way to the soil surface. The operator can increase the hole diameter as the waterjet is pulled back up out of the hole by rotating the nozzle side to side. The rotation should continue the entire length of the hole.

Once the hole has been hydrodrilled, immediately push a single cutting or a bundle of 3 to 4 cuttings into the hole. The longer the user waits to plant the cutting, the greater the chance the suspended sediment will settle to the bottom of the hole and limit the depth that the cutting can be inserted.

An alternative option is to start the hole with the waterjet and then place the cutting or bundle next to the waterjet pipe and push both the waterjet and the cuttings into the hole at the same time. If done properly, the cutting or bundle will go down as the waterjet liquefies the soil. If the cutting hits a tight spot, the operator will immediately know it and can spiral the nozzle around to loosen the obstruction. A word of caution: make sure that the cutting does not extend past the nozzles or the pressurized water will cut the bark off.

We have observed problems associated with drilling through fine soils into coarse soils. When the waterjet penetrates through the fine soil, the water in the hole will drain out into the coarse layer. This will defeat the purpose of planting the cuttings into a slurry to eliminate air pockets. Retracting the waterjet nozzle up to just above the coarse textured layer will allow sediment to settle back into the bottom of the hole and reseal it. The Waterjet Stingers do not provide an advantage over

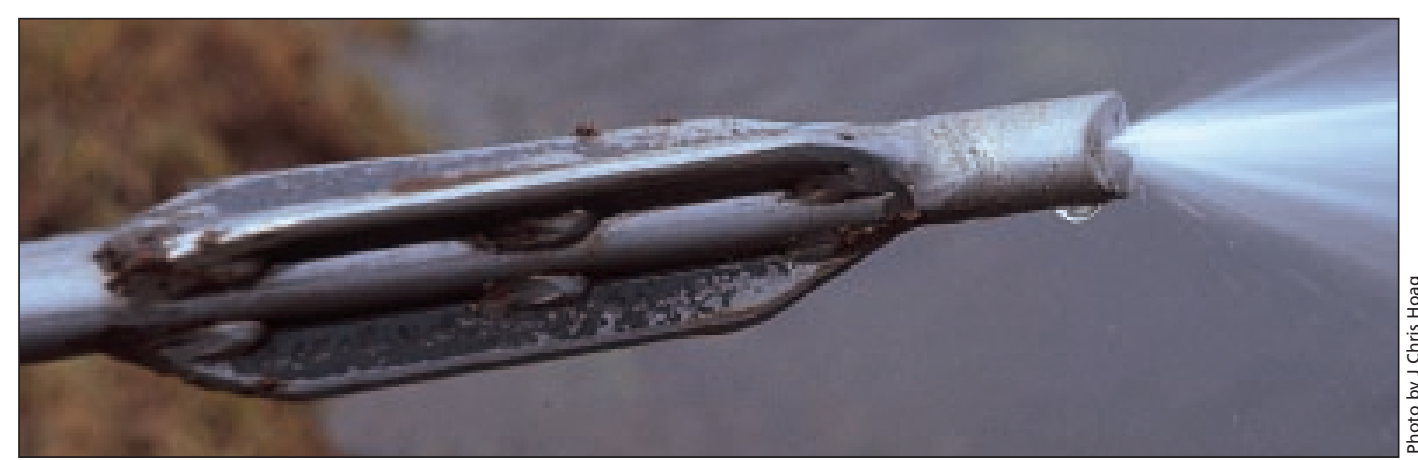

Figure 5 - Vanes on the probe, just above the nozzle, enhance performance in clay and silt soils. 
other planting methods in cobbly soils because the cobbles prevent the probes from drilling deep into the soil.

We have found that 3 people per waterjet is efficient for planting. One team member operates the waterjet and the other 2 members haul cuttings and plant them in the holes. Rotating jobs for the members throughout the planting day keeps everyone fresh and interested in the planting job. An extra person to transport cuttings from the soaking location to the planting location also improves efficiency. The speed of the entire planting process will depend upon soil, labor force, and cutting or bundle sizes.

Once the cutting is planted to the depth of the low water table, the sediment will start to settle around the stem. It is important that the operator not allow significant amounts of sediment to bubble up out of the hole while drilling. The more sediment that is allowed to bubble out, the more soil that will have to be replaced-as the water moves out into surrounding soil, the soil in the hole settles and leaves a depression around the cutting. After planting, the team can return to each cutting and refill the depression. By replacing soil around the cutting, it is possible to provide more opportunity for root development in the upper part of the soil profile. When replacing the soil, use a mud slurry or tamp shoveled soil around the stem to prevent air pockets.

\section{SAFETY}

Before beginning any planting project, discuss safety with the planting team members. This ensures that proper safe working conditions are fresh in everyone's mind before beginning. The water coming out of the waterjet nozzles is concentrated and under extremely high pressure. If the waterjet nozzle were ever pointed at a foot or hand, it could cut through a boot or glove and into the skin. Severe damage could occur if the nozzle were pointed at the face, eyes, or any unprotected part of the body. The waterjet stinger is not a toy and should always be operated by, or at least supervised by, an experienced, mature adult. Caution should always be exercised around the pump. Inspect the hoses regularly to ensure that they are not kinked, cut, or abraded. The quick couple hose attachments should be tested several times during the operation of the Waterjet Stinger to ensure they are firmly attached. If for some reason the hoses are disconnected from the waterjets, shut the pump down immediately to ensure the metal tipped ends do not whip around and hurt one of the team members. It is much better to anticipate and discuss safety concerns than to heal the wounds caused by a mistake or faulty equipment.

\section{SUMMARY}

The Waterjet Stinger is easy to operate and transport. Very little training is necessary to operate the Waterjet Stinger. The pump intake should be placed in a fairly sediment free location in the streambed to operate properly. Hydrodrilling a planting hole with the Waterjet Stinger is fast and relatively splash-free. A large number of cuttings can be planted in a short period of time with very little effort compared to conventional planting methods. Planting into a hole filled with water allows each cutting to be planted directly into a wet microenvironment. The liquefied soil will settle around the cutting eliminating air pockets in the rooting zone that prevents root growth. In addition, the Waterjet Stinger creates saturated soil conditions around the cutting for a longer period of time. This means the cutting is in the best microenvironment to produce the largest and most desirable root mass possible, which in turn means that the establishment success rate will increase.

Overall, the waterjet stinger is relatively inexpensive when compared to other planting methods. The prototype Waterjet Stinger cost about US \$1200 for parts (all can be ordered or purchased locally, except the pump) and US \$500 for labor (assembly takes less than a day). The design layout was planned to make the entire piece of equipment as simple as possible to build and operate. An experienced machinist can build the waterjet nozzle in a couple of hours with the plans provided.

\section{ACKNOWLEDGEMENTS}

The development of the Waterjet Stinger would not be possible without the support and the generous financial assistance provided by the South Bingham, Gem, Squaw Creek, and Camas soil and water conservation districts; and Dick Scully, Regional Fisheries Biologist, Southeast Region, Idaho Department of Fish And Game.

\section{REFERENCES}

Andrews D. 1999. Personal communication. Winnipeg (ON): Canada: Denis Andrews Consulting.

Bentrup G, Hoag JC. 1998. The practical streambank bioengineering guide - A user's guide for natural streambank stabilization techniques in the arid and semi-arid Great Basin and Intermountain West. Aberdeen (ID): USDA NRCS Plant Materials Center, Interagency Riparian/Wetland Plant Development Project. 169 p.

Drake L, Langel R. 1998. Deep-planting willow cuttings via water jetting. ASCE Wetlands Engineering \& River Restoration Conference; 1998 Mar 22--27; Denver, Colorado. Section M. 6 p.

Hoag JC, Ogle D. 1994. The Stinger, a tool to plant unrooted hardwood cuttings of willow and cottonwood species for riparian or shoreline erosion control or rehabilitation. Boise (ID): USDA Natural Resources Conservation Service. Idaho Plant Materials Technical Note No. 6. 13 p.

Hoag JC. 1993. How to plant willows and cottonwoods for riparian rehabilitation. Boise (ID): USDA Natural Resources Conservation Service. Idaho Plant Materials Technical Note No. 23. 12 p.

Oldham JA. 1991. The hydrodriller: an efficient technique for installing woody stem cuttings. Fesno (CA): USDA Natural Resources Conservation Service, Kings River Conservation District. Research Report No. 91-02. 8 p.

USDA NRCS. 2001. The PLANTS database, Version 3.0. URL: http://plants.usda.gov/plant (accessed 23 May 2001). Baton Rouge (LA): National Plant Data Center.

\section{AUTHOR INFORMATION}

J Chris Hoag

Wetland Plant Ecologist

chris.hoag@id.usda.gov

Boyd Simonson

Biological Technician

boyd.simonson@id.usda.gov

Brent Cornforth

Biological Technician

brent.cornforth@id.usda.gov

Loren St John

PMC Team Leader

loren.st.john@id.usda.gov

USDA Natural Resources

Conservation Service

Plant Materials Center

PO Box 296

Aberdeen, ID 83210 